\title{
Anti-HER2 Monoclonal Antibody
}

National Cancer Institute

\section{Source}

National Cancer Institute. Anti-HER2 Monoclonal Antibody. NCI Thesaurus. Code C155711.

Any monoclonal antibody that is directed ag ainst human epidermal growth factor receptor 2 (HER2; HER-2; ERBB2). 